Egyptian Journal of Aquatic Biology \& Fisheries

Zoology Department, Faculty of Science,

Ain Shams University, Cairo, Egypt.

ISSN $1110-6131$

Vol. 25(3): 1059 - 1078 (2021)

www.ejabf.journals.ekb.eg

\title{
Monitoring of Heavy Metals in Major Drains and Farms at Fayoum Government and Treatment by Pumpkin and Eggplant
}

\author{
Ghada Taha Belal ${ }^{1}$,*, Hala Elshahat Ghannam ${ }^{1}$ and Soha Mohamed Hamdy ${ }^{2}$ \\ ${ }^{1}$ Pollution Laboratory, Freshwater and Lakes Division, National Institute of Oceanography and \\ Fisheries, Cairo, Egypt. \\ ${ }^{2}$ Chemistry Department, Faculty of Science, Fayoum University, Fayoum, Egypt. \\ "Corresponding Author: gh_belal96@yahoo.com
}

\section{ARTICLE INFO}

Article History:

Received: May 22, 2021

Accepted: June 27, 2021

Online: June 30, 2021

Keywords:

Drainage water,

Farm water,

Nile tilapia,

Heavy metals,

Biochemical parameters.
ABSTRACT

This study was carried out in three different farms and drainages at ELFayoum Government in Egypt. Five heavy metals $(\mathrm{Zn}, \mathrm{Cd}, \mathrm{Pb}, \mathrm{Fe}$ and $\mathrm{Cu}$ ) were addressed in farms and drain water. The organs (gills, skin, muscles and liver) and blood of selected fish; gathered from various farms and drains, were examined to measure the heavy metals' residue. The results showed that, iron was the most accumulated metal in the three drains and farms, while zinc was the most accumulated metal in the Nile tilapia blood. For water treatment, pumpkin showed high removal of $\mathrm{Zn}(65 \%)$ and $\mathrm{Pb}$ (50\%), while eggplant gave maximum removal values of $\mathrm{Fe}, \mathrm{Cd}$ and $\mathrm{Cu}$ (88\%, $78 \%$ and $77 \%$, respectively). In the current study, investigation of some biochemical blood parameters were also determined, such as alanine aminotransferase, aspartate aminotransferase enzyme, urea, creatinine, random blood sugar, creatinine kinase, alkaline phosphatase and thyroidstimulating hormone, thyroxine and triiodothyronine, growth hormone and cortisol hormones.

\section{INTRODUCTION}

Drain water is the removal of a surface water from an area with high amount of water whether naturally or industrially originated. Water is carried to outlet by main drains collecting water from the laterals. Sub mains branched from the main drain are used to collect water (Dalrymple, 2015). In Egypt, the annual supply of water is about 57.7 billion cubic meters collected from the Nile, rainfall along the Mediterranean coast and the deep groundwater as well. However, the estimated used water for farms, industries, and people is around $72.4 \mathrm{BCM}$ (Barnes, 2014). It is noteworthy to mention that, most of the heavy metals are bound to particles in sediment, though a small quantity is dissolved in water and can spread widely mounting the atmost top of the food chain (El-Nemeki et al., 2008). Furthermore,wells, rivers, dams and large ponds are good sources of water for fish farm ponds (Gabbadon \& De Souza, 2008). Hence, aquatic organisms are exposed to high levels of heavy metals. Since fish are relatively sensitive 
to changes in their surroundings environment, fish health would indicate a good sign of the health state of a specific aquatic ecosystem. Remarkably, poisonous effects of pollution appear on cellular or tissue level early before significant changes can be observed in fish behavior or external appearance (Abdel-Warith et al., 2011). Moreover, blood is a path physiological reverse of the all body parts. Consequently, blood parameters are important in examining the structural and functional state of fish insecure to toxicants. Eminently, variation in the biochemical blood factors indicate changes in metabolism and biochemical processes of the organism due to the effects of various pollutants (Adhikari et al., 2004). The levels of serum enzymes have been widely used as indicators of health for different animals like fish. Hence, the evaluation of those blood components may help to determine the influence of stressors on the homeostasis of those animals, especially fish enabling the detection of early conditions that could be affecting the production performance (Cnaani et al., 2004). It was noticed that, metal ions can be joined to food chains and fixed in aquatic organisms to a level that affects their physiological state. In this essence, zinc, copper and iron have a biochemical role in the life processes of all aquatic organisms especially fish as they are essential in the aquatic environment in little amounts (Saeed \& Shaker, 2008). Pollution of the aquatic environment is a sign of danger and may cause problems around the world. The highest amount of industrial, agricultural and commercial chemicals spreading into the aquatic environment have various dangerous impacts on aquatic organisms. Thus, heavy metals' residue of aquatic system has gained the interest of several researchers (Yacoub \& Gad, 2012). Residue of heavy metals varied due to species, ages, sex and organs. Liver and gills have metabolic activity where high levels of metal are accumulated in fish, while in muscles the metabolic activity is relatively low accumulating less level of heavy metals (Younis et al., 2002). Eminently, residue activities in fish tissues depends on metal condensation (i.e: metal concentration), time of exposition, metal uptake, environmental conditions (water nuclear fuels, temperature, $\mathrm{pH}$, hardness, salinity), fish age and feeding habits. The tiny size of heavy metals are various in affinity to penetrate fish tissues allowing toxic metals to be released into liver, kidney, gills and fish muscles. Comparing to the other mentioned tissues, fish muscles usually include the lowest levels of metals. Residue of heavy metals in different organs of fish may cause structural damage and commonly lead to functional disturbances (Jezierska \& Witeska, 2006). Therefore, the aim of the present study was to follow up the effect of different sources of drainage on fish farms in Fayoum Governorate by collecting water and fish samples from farms and measuring five heavy metals ( $\mathrm{Fe}, \mathrm{Cu}, \mathrm{Zn}, \mathrm{Cd}$ and $\mathrm{Pb}$ ). The accumulation of those metals in water, different fish organs and fish blood were examined. Moreover, low cost adsorbent such as eggplant and Cucurbita pepo were used to treat heavy metals in the highly polluted drain. Moreover identification of biochemical changes like glucose, liver enzymes, kidney functions, triglycerides, cortisol hormone, growth hormone and thyroid hormones was also studied.

\section{MATERIALS AND METHODS}

The experiment was carried out in Shakshouk Fish Research Station, EL-Fayoum Governorate, National Institute of Oceanography and Fisheries, Egypt. 


\section{Collection of Water and Fish samples}

Water samples were collected from three major different drainages at EL-Fayoum Governorate (Dier El-Berka, EL-Wadi and EL-Bats drains) and three different commercial farms where those drains pour into (EL-Gilani, Locanda and EL-Bats farms, respectively) from middle site. Fish samplesof the Nile tilapia (Oreochromis niloticus) were collected from three different commercial farms (EL-Gilani, Locanda and EL-Bats) with weights ranging from 170-230 grams and lengths from $20-25 \mathrm{~cm}$.

\section{Heavy metals contamination}

Heavy metal determination ( $\mathrm{Fe}, \mathrm{Pb}, \mathrm{Zn}, \mathrm{Cu}$ and $\mathrm{Cd}$ ) in water samples was determined using Atomic Absorption (Perkin Elmer 3110 USA) with graphite atomizer HGA-600 at Soil and Water Laboratory, Faculty of Agriculture, Fayoum University.

\section{Treatment of water drainage}

Water samples were collected from EL-Bats drain from middle site for treatment using two adsorbent pumpkin (Cucurbita pepo) and eggplant (Solanummelongena)

\section{Preparation of pumpkin (Cucurbita pepo)}

A pumpkin is a cultivar of the squash plant, most commonly of Cucurbita pepo, it is round, with smooth, slightly ribbed skin, and deep yellow to orange coloration. Pumpkin is easily available at the local market and was purchased and prepared for treatment of heavy metals. The seeds were sun dried for 2-3 days followingthe method of Deepthi (2017). The dried seeds were pulverized into a fine powder using a pestle and mortar (Fig. 1). The required dosage $(0.5 \mathrm{~g} / \mathrm{l})$ of pulverized seed material was made into a paste using a small amount of water mixed and shaken for 1 min to activate the coagulant properties of the seed at stilling time of $30 \mathrm{~min}$.

\section{Preparation of eggplant peel adsorbent}

The eggplant was collected from the local market and prepared for treatment of heavy metals. The outer peel was removed then the waste peel was immersed in an $\mathrm{HCl}$ solution $(0.01 \mathrm{M})$ to remove other impurities for $24 \mathrm{~h}$. After $\mathrm{HCl}$ treatment, the waste eggplant peel was washed with D.W. and then obscure in $1 \mathrm{M} \mathrm{NaOH}$ solution for $48 \mathrm{~h}$ (Min et al., 2004). Next, it was rinsed with D.W. and heated in a temperature of $60^{\circ} \mathrm{C}$ for 30 hours in a drying oven. The dried adsorbents were ground using grinding machine and sieved with standard mesh size into sizes of $200 \mathrm{~mm}$ (Fig. 1) then, $4 \mathrm{~g} / \mathrm{l}$ of powder was used as dosage in an optimum time of $110 \mathrm{~min}$ for experiment.
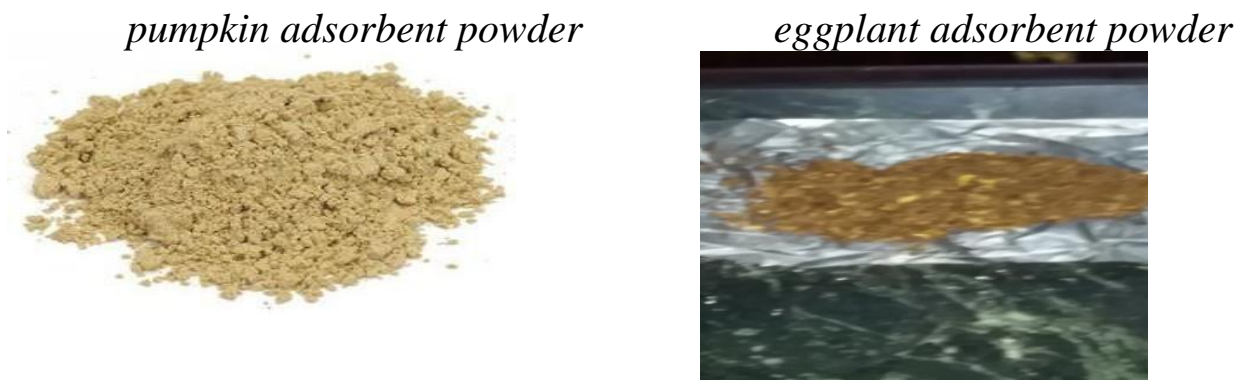

Fig. 1. Pumpkin and Eggplant Adsorbent Powders.

\section{Blood analysis}

Blood samples were taken from the caudal vein of un anaesthetized fish, 1-3 $\mathrm{ml}$ of blood was collected from each individual in a clean centrifuge tube. Serum was then separated by centrifuge at 3000 r.p.m for $15 \mathrm{~min}$ to be used for estimation of glucose 
levels, creatinine kinase, alkaline phosphatase, urea, creatinine, AST, ALT , cortisol hormone, growth hormone, thyroid hormones (TSH, T3, T4) and heavy metals levels (cadmium, zinc, iron, lead and copper). Serum glucose concentration was determined according to the method of Trinder (1969). Serum ALP was carried out according to Tietz et al. (1983). Serum CK was carried out according to German clinical chemistry society (1977). Serum cortisol was formed according to Tunn et al. (1990). Serum T3 was carried following the descriptions of Wild (1994), serum T4 was carried out foolowing Chopra (1972), serum TSH was formed using the steps of Morimoto and Inouye (1997). In addition, growth hormone in plasma using ELISA Kit was determined according to Baum $\boldsymbol{e t}$ al. (1998). Samples for heavy metals analysis were submitted to Analytical Toxicology Laboratory Services and the analysis was done according to the procedures of Gajek $\boldsymbol{e t}$ al. (2013) by Inductively Coupled Plasma Mass Spectrometry (ICP-MS).

\section{Accumulation of heavy metals in different fish organs}

Fish specimens were transferred to beakers and placed in a drying oven thermostatically regulated at $105^{\circ} \mathrm{C}$ overnight. Representative samples $(10 \mathrm{~g}$ fresh muscles, $3 \mathrm{~g}$ for liver, $10 \mathrm{~g}$ for gills and $3 \mathrm{~g}$ for skin) of dry weight were taken from the fish specimens. The samples were digested according to the method described by Goldberg (1963).

\section{Statistical analysis}

The data were analyzed by one-way ANOVA and significant differences were determined by Duncan Waller Multiple Range Test at 5\% level using SPSS Statistical Package Program (SPSS, 2008) 17, released version.

\section{RESULTS}

\section{Heavy metals concentrations in three different water drainages before treatment}

Figs. 2 and 3 show that, there was a significant decrease of $\mathrm{Zn}$ and $\mathrm{Cd}$ with $P$ value $(0.02,0.02$ respectively ) in EL-Wadi drainage and mean value \pm S.D of $Z n$ levels in EL-Bats drain with $P$ - value ( 0.001 ) when compared to Dyer EL-Berka drainage and $P^{*}$ - value of 0.02 and 0.01 when compared to EL-Wadi drainage.

Additionally, a significant increase of $\mathrm{Fe}$ and $\mathrm{Cu}$ was detected in EL-Wadi and EL-Bats drains with $P$-value of $0,002,0.002$ and $0.003,0.003$, respectively when compared to Dyer EL-Berka drainage, while $P^{*}$ - value of $0.5,0.01$ was observved when compared to EL-Wadi drainage. Moreover, Cd recorded a significant increase of mean value \pm S.D in EL-Bats drains with a $P$-value of 0.02 when compared to Dyer EL-Berka drainage, and a $P^{*}$-value of 0.01 when compared to EL-Wadi drainage. But, a nonsignificant variation of $\mathrm{Pb}$ was recorded in EL-Wadi and EL-Bats drains when compared to Dyer EL-Berka drainage. 


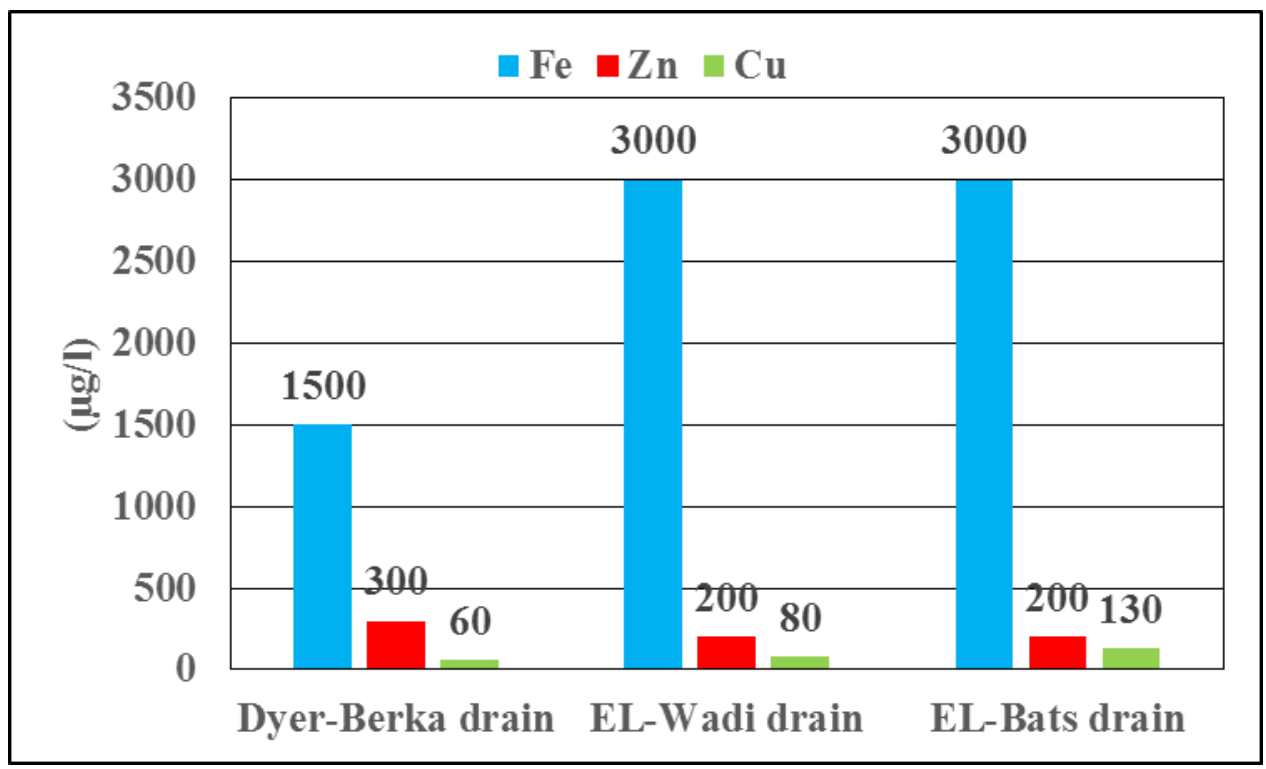

Fig. 2. $\mathrm{Fe}, \mathrm{Zn}$ and $\mathrm{Cu}$ Concentrations $(\mu \mathrm{g} / \mathrm{l})$ in Three Different Water Drainages.

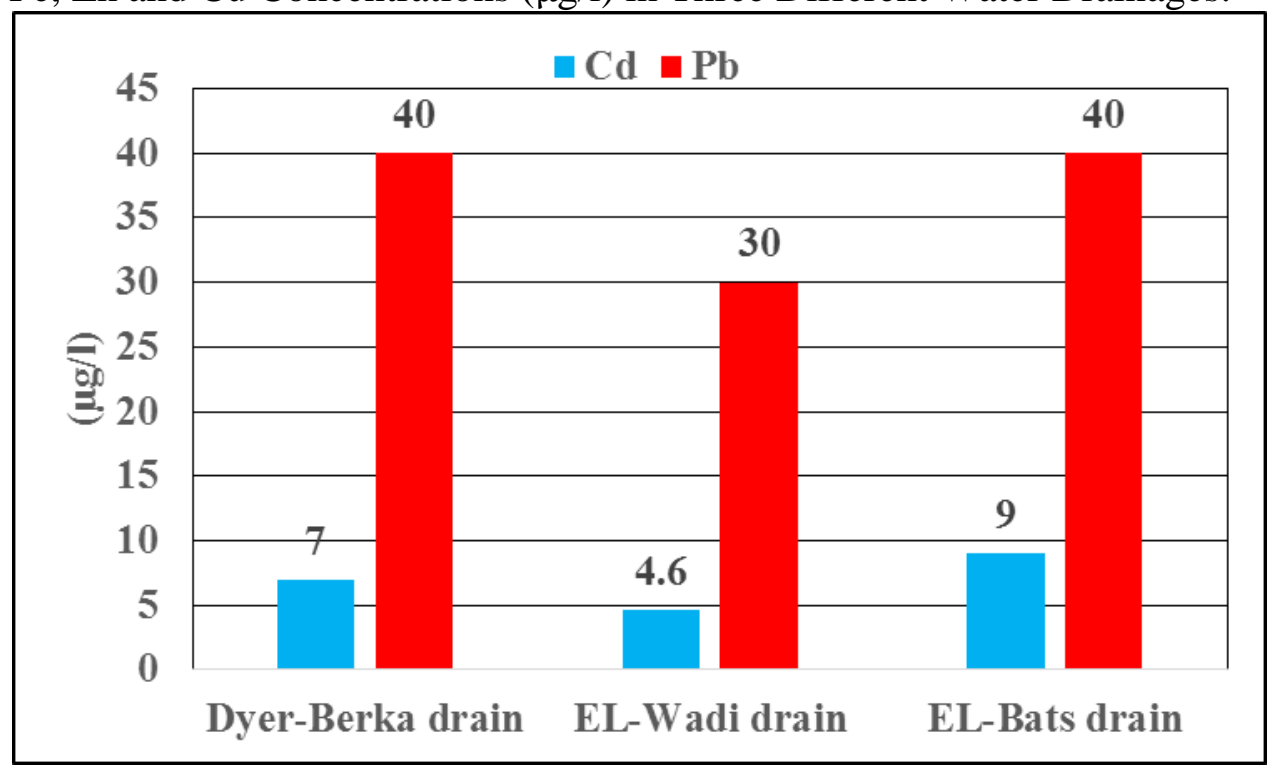

Fig. 3. $\mathrm{Cd}$ and $\mathrm{Pb}$ Concentrations $(\mu \mathrm{g} / \mathrm{l})$ in Three Different Drainages.

\section{Heavy metal concentrations in the water of three different farms}

As shown in Fig $(4,5)$, a significant decrease was detected in the levels of $\mathrm{Zn}$ and Fe in Locanda and EL-Bats farms with $P$-value of $0.001,0.001$ for $\mathrm{Zn}$, and $<0.001$, $<0.001$ for Fe, respectively. However, an increased value of Fe was detected in EL-Bats when compared to EL-Galini farm recording $P^{*}$ - value $<0.001,0.01$ when compared to Locanda farm. 


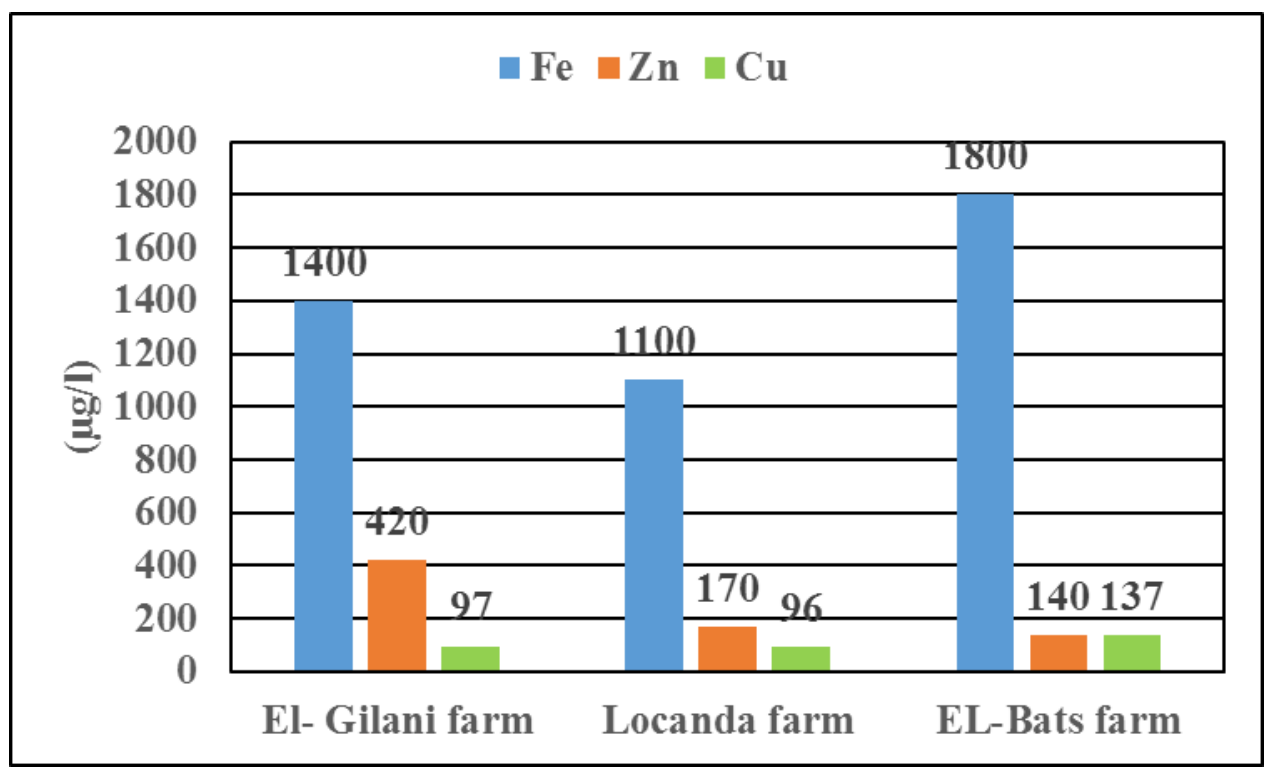

Fig. 4. Fe, $\mathrm{Zn}$ and $\mathrm{Cu}$ Concentrations in Water of Three Different Fish Farms.

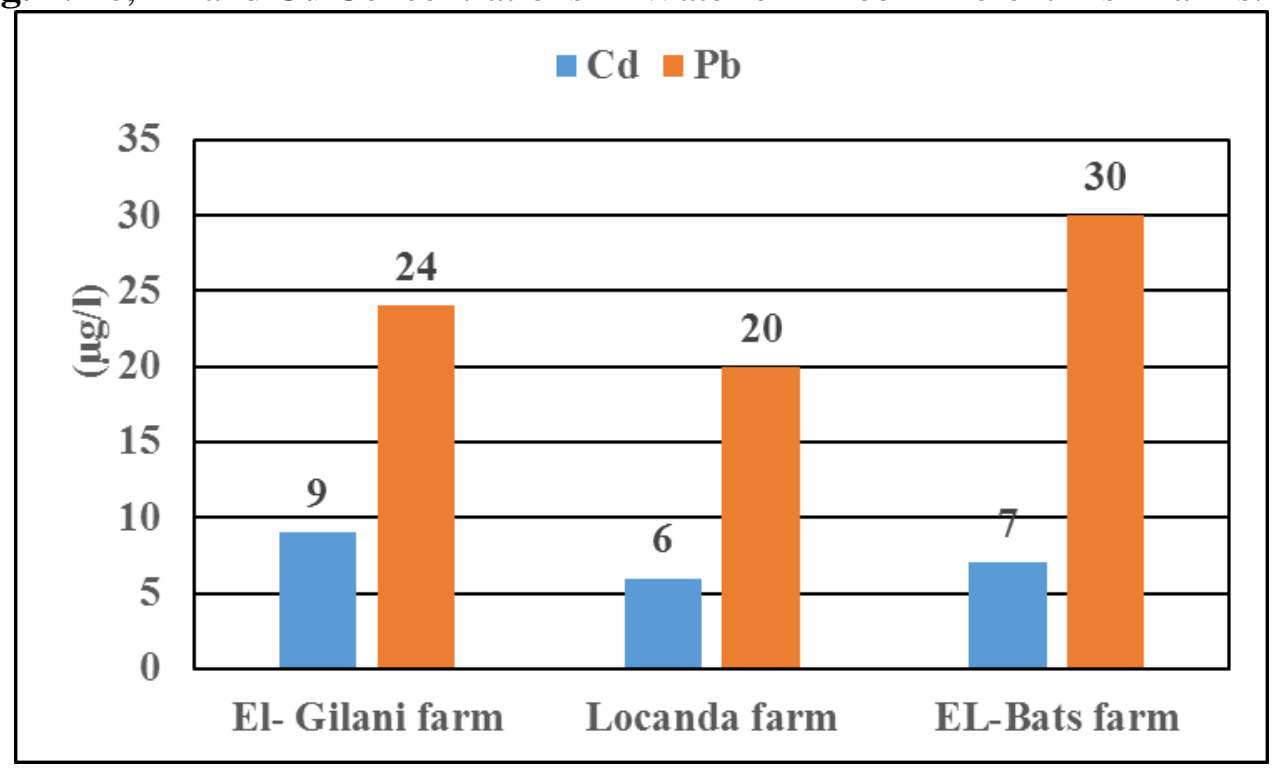

Fig. 5. $\mathrm{Cd}$ and $\mathrm{Pb}$ Concentrations in Water of Three Different Fish Farms.

On the other hand, there was a significant increase of levels of $\mathrm{Cu}$ in EL-Bats farms with a $P$-value of 0.004 and $P^{*}$ - value of 0.001 when compared to Locanda farm. In addition, a non-significant variation was recorded in Locanda farm when compared to EL-Galini farm. While, non-significant levels of $\mathrm{Cd}$ and $\mathrm{Pb}$ were dedermined in both Locanda and EL-Bats when compared to EL-Galini farm.

\section{Treatment by pumpkin}

The removal of different metals using prepared adsorbent from pumpkin is explained in Table (1). It is clear that, this adsorbent showed a good removal of all the metal at dosage of adsorbent $(0.5 \mathrm{~g} / \mathrm{l})$ contact time $30 \mathrm{~min}$ and temperature $25^{\circ} \mathrm{C}$. Table (1) records a significant decrease of levels of $\mathrm{Zn}, \mathrm{Cu}, \mathrm{Fe}$ and $\mathrm{Pb}$ with $P$-value of 0.01 , $0.001,<0.001$ and 0.05 , respectively in EL-Bats drain under effect of treatment by pumpkin when compared to EL-Bats drain before treatment. But, Cd levels showed non- 
significant variation in EL-Bats drain under effect of treatment by pumpkin when compared to EL-Bats drain before treatment. It was clear from the obtained results that, the order of removal for the different heavy metals followed the succeeding order: Fe> $\mathrm{Cd}>\mathrm{Zn}>\mathrm{Cu}>\mathrm{Pb}$. For $\mathrm{Fe}$, the maximum removal was $77 \%$, while the minimum was recorded for $\mathrm{Pb}$ recording a removal value of $50 \%$.

\section{Treatment by eggplant}

The prepared adsorbent from eggplant was also examined for the removal of heavy metals from the polluted drain Table (2). The results showed that this adsorbent give high percent of metal removal at an adsorbent dose of $4 \mathrm{~g} / \mathrm{l}$, contact time of $110 \mathrm{~min}$ and temperature of $25^{\circ} \mathrm{C}$. It was noticed from the results that are presented in Table (2) that, levels of $\mathrm{Zn}, \mathrm{Cu}, \mathrm{Fe}$ and $\mathrm{Cd}$ recorded a significant decrease with $P$-value of 0.02 , $0.001,0.001$ and 0.01 , respectively in EL-Bats drain under effect of treatment by eggplant when compared to EL-Bats drain before treatment. Nevertheless, the Pb levels of mean value \pm S.D showed a non-significant variation in EL-Bats drain under effect of treatment with eggplant when compared to EL-Bats drain before treatment. Consequently, the order of removal for the different heavy metal were as follows: Fe> $\mathrm{Cd}>\mathrm{Cu}>\mathrm{Zn}$ and $\mathrm{Pb}(\mathrm{Zn}$ and $\mathrm{Pb}$ showed equal removal percentage). The maximum removal $88 \%$ for $\mathrm{Fe}$, while the minimum was $25 \%$ for $\mathrm{Zn}$ and $\mathrm{Pb}$ under effect of treatment with eggplant.

Table 1. Heavy Metals Concentrations ( $\mu \mathrm{g} / \mathrm{l})$ in EL-Bats Water Drainage before and after Treatment with pumpkin.

\begin{tabular}{|c|c|c|c|c|}
\hline \multicolumn{2}{|c|}{$\begin{array}{ll}\text { Geavy metals } & \text { Groups } \\
\text { Hen }\end{array}$} & Before & After & $\begin{array}{l}\text { percent of } \\
\text { removal \% }\end{array}$ \\
\hline $\begin{array}{l}\text { Zinc } \\
(\mu \mathrm{g} / \mathrm{l})\end{array}$ & $\begin{array}{c}\text { Range } \\
\text { Means } \pm \text { SD } \\
p \text {-value }\end{array}$ & $\begin{array}{l}200-205 \\
200 \pm 3.5\end{array}$ & $\begin{array}{c}70-75 \\
70 \pm 3.5 \\
0.012\end{array}$ & 65 \\
\hline $\begin{array}{l}\text { Copper } \\
(\mu \mathrm{g} / 1)\end{array}$ & $\begin{array}{c}\text { Range } \\
\text { Means } \pm \text { SD } \\
p \text {-value }\end{array}$ & $\begin{array}{l}130-135 \\
130 \pm 3.5\end{array}$ & $\begin{array}{c}50-54 \\
50 \pm 2.8 \\
0.001\end{array}$ & 62 \\
\hline $\begin{array}{l}\text { Iron } \\
(\mu \mathrm{g} / \mathrm{l})\end{array}$ & $\begin{array}{c}\text { Range } \\
\text { Means } \pm \text { SD } \\
p \text {-value }\end{array}$ & $\begin{array}{c}3000-3010 \\
3000 \pm 7.0\end{array}$ & $\begin{array}{c}700-720 \\
700 \pm 14.1 \\
<0.001\end{array}$ & 77 \\
\hline $\begin{array}{l}\text { Lead } \\
(\mu \mathrm{g} / \mathrm{l})\end{array}$ & $\begin{array}{c}\text { Range } \\
\text { Means } \pm \text { SD } \\
p \text {-value }\end{array}$ & $\begin{array}{c}40-45 \\
40 \pm 3.5\end{array}$ & $\begin{array}{c}20-24 \\
20 \pm 2.8 \\
0.03 \\
\end{array}$ & 50 \\
\hline $\begin{array}{l}\text { Cadmium } \\
(\mu \mathrm{g} / \mathrm{l})\end{array}$ & $\begin{array}{c}\text { Range } \\
\text { Means } \pm \text { SD } \\
p \text {-value }\end{array}$ & $\begin{array}{c}9-10 \\
9 \pm 0.3\end{array}$ & $\begin{array}{c}3-5 \\
3 \pm 1.4 \\
0.09\end{array}$ & 67 \\
\hline
\end{tabular}

- Data are represented as means $\pm S D ;-P$-value :-when different groups compared to EL-Bats drain; $p>0.05$ is non-significant - $p \leq 0.05$ is significant. 
Table 2. Heavy Metals Concentrations $(\mu \mathrm{g} / \mathrm{l})$ in EL-Bats Water Drainage before and after Treatment with Eggplant.

\begin{tabular}{|c|c|c|c|c|}
\hline \multicolumn{2}{|c|}{$\mathrm{P}_{\text {Heavy metals }}^{\text {Groups }}$} & Before & After & $\begin{array}{l}\text { percent of } \\
\text { removal \% }\end{array}$ \\
\hline Zinc $(\mu \mathrm{g} / \mathrm{l})$ & $\begin{array}{c}\text { Range } \\
\text { Means } \pm \text { SD } \\
p \text {-value }\end{array}$ & $\begin{array}{l}200-205 \\
200 \pm 3.5\end{array}$ & $\begin{array}{c}150-154 \\
150 \pm 2.8 \\
0.02\end{array}$ & 25 \\
\hline Copper $(\mu \mathrm{g} / \mathrm{l})$ & $\begin{array}{c}\text { Range } \\
\text { Means } \pm \text { SD } \\
p \text {-value }\end{array}$ & $\begin{array}{l}130-135 \\
130 \pm 3.5\end{array}$ & $\begin{array}{c}31-34 \\
31 \pm 2.1 \\
0.001\end{array}$ & 77 \\
\hline Iron $(\mu \mathrm{g} / \mathrm{l})$ & $\begin{array}{c}\text { Range } \\
\text { Means } \pm \text { SD } \\
p \text {-value }\end{array}$ & $\begin{array}{c}3000-3010 \\
3000 \pm 7.0\end{array}$ & $\begin{array}{c}354-355 \\
355 \pm 0.7 \\
0.001 \\
\end{array}$ & 88 \\
\hline Lead $(\mu \mathrm{g} / \mathrm{l})$ & $\begin{array}{c}\text { Range } \\
\text { Means } \pm \text { SD } \\
p \text {-value }\end{array}$ & $\begin{array}{c}40-45 \\
40 \pm 3.5\end{array}$ & $\begin{array}{c}30-34 \\
30 \pm 2.8 \\
0.08 \\
\end{array}$ & 25 \\
\hline Cadmium $(\mu \mathrm{g} / \mathrm{l})$ & $\begin{array}{c}\text { Range } \\
\text { Means } \pm \text { SD } \\
p \text {-value }\end{array}$ & $\begin{array}{c}9-10 \\
9 \pm 0.3\end{array}$ & $\begin{array}{c}2-3 \\
2 \pm 0.7 \\
0.01\end{array}$ & 78 \\
\hline
\end{tabular}

- Data are represented as means $\pm S D ;-P$-value :-when different groups compared to EL-Bats drain; $p>0.05$ is non- significant

- $p \leq 0.05$ is significant.

\section{Biochemical parameter levels of fish blood in three different farms}

Table (3) shows a significant increase of RBS and ALP with $P$-value of 0.004 , 0.002 for RBS and 0.01, 0.001 for ALP, respectively in both Locanda and EL-Bats farms when compared to EL-Galini farm and $P^{*}$-value of 0.002 and 0.001 when compared to Locanda farm.

Table 3. Biochemical Parameters in Fish Blood of Three Different Farms.

\begin{tabular}{|c|c|c|c|c|}
\hline \multicolumn{2}{|c|}{$\begin{array}{c}\text { Groups } \\
\text { Biochemical }\end{array}$} & $\begin{array}{c}\text { EL-Galini } \\
\text { Farm }\end{array}$ & $\begin{array}{c}\text { Locanda } \\
\text { Farm }\end{array}$ & $\begin{array}{c}\text { EL-Bats } \\
\text { Farm }\end{array}$ \\
\hline & Range & $61.0-61.23$ & $108.0-108.09$ & $82.0-82.52$ \\
RBS & Means \pm SD & $61.12 \pm 0.16$ & $108.46 \pm 0.65$ & $82.26 \pm 0.36$ \\
$(\mathrm{mg} / \mathrm{dl})$ & $p$-value & & 0.004 & 0.002 \\
& $P^{* \text {-value }}$ & & & 0.002 \\
\hline & Range & $16.4-16.4$ & $13.04-13.04$ & $2.6-23.5$ \\
Urea & Means \pm SD & $16.4 \pm 0.01$ & $13.04 \pm 0.01$ & $23.05 \pm 0.63$ \\
$(\mathrm{mg} / \mathrm{dl})$ & $p$-value & & $<0.001$ & 0.04 \\
& $P^{*}$-value & & & 0.03 \\
\hline & Range & $0.86-0.86$ & $0.64-0.65$ & $0.60-0.70$ \\
Creatinine & Means \pm SD & $0.86 \pm 0.01$ & $0.64 \pm 0.01$ & $0.65 \pm 0.07$ \\
$(\mathrm{mg} / \mathrm{dl})$ & $p$-value & & 0.02 & 0.05 \\
& $P^{* \text {-value }}$ & & & $<0.001$ \\
\hline
\end{tabular}




\begin{tabular}{|c|c|c|c|c|}
\hline & Range & $21.2-21.6$ & $123.56-123.58$ & $16.0-18.52$ \\
ALT & Means \pm SD & $21.41 \pm 0.29$ & $123.57 \pm 0.01$ & $18.26 \pm 0.36$ \\
$(\mathrm{U} / \mathrm{L})$ & $p$-value & & 0.01 & 0.01 \\
& $P^{*}$-value & & & 0.002 \\
\hline & Range & $340.0-340.0$ & $154.27-154.4$ & $111.8-111.9$ \\
AST & Means \pm SD & $340.00 \pm 0.01$ & $154.30 \pm 0.14$ & $111.8 \pm 0.07$ \\
$(\mathrm{U} / \mathrm{L})$ & $p$-value & & $<0.001$ & $<0.001$ \\
& $P^{*}$-value & & & $<0.001$ \\
\hline Alkaline & Range & $30.0-30.9$ & $81.51-81.52$ & $105.5-105.6$ \\
phosphatase & Means \pm SD $p$ - & $30.4 \pm 0.64$ & $81.52 \pm 0.01$ & $105.65 \pm 0.21$ \\
$($ ALP) (IU/L) & value $P^{*}-$ & & 0.01 & 0.001 \\
& value & & & 0.001 \\
\hline & Range & $20952-20952.1$ & $7215.9-7216.0$ & $9157.8-9158.0$ \\
Creatinine kinase & Means \pm SD & $20952.52 \pm 0.7$ & $7257.90 \pm 0.07$ & $9157.90 \pm 0.14$ \\
$(\mathrm{CK})(\mathrm{mg} / \mathrm{dl})$ & $p$-value & & $<0.001$ & $<0.001$ \\
& $P^{*}$-value & & & $<0.001$ \\
\hline
\end{tabular}

-Data are represented as means $\pm S D$ of 3 farms; P-value :- when different groups compared to EL-Galini farm.; P*-value :when different groups compared to Locanda farm.; $p>0.05$ is non-significant - $p \leq 0.05$ is significant $-S D \pm$ standard deviation

Additionally, there was a significant decrease of of creatinine, CK and AST with $P$-value of 0.02, 0.05 for creat., $<0.001,<0.001$ for CK and $<0.001,<0.001$ for AST, respectively in both Locanda and EL-Bats farms when compared to EL-Galini farm, recording a $P^{*}$-value $(<0.001)$ when compared to Locanda farm. On other hand, there was a significant decrease of urea in Locanda farm with $P$-value $(<0.001)$ but, a significant increase with $P$-value $(0.04)$ was detected in EL-Bats farm when compared to EL-Galini farm and $P^{*}$-value (0.03) was regarded when compared to Locanda farm. The current results detected a significant increase of ALT in Locanda farm with a $P$-value of 0.01 . Meanwhile, a significant decrease with a $P$-value of 0.01 was recorded in EL-Bats farm when compared to EL-Galini farm and $P^{*}$-value $(0.002)$ as detected when compared to Locanda farm.

\section{Hormone levels in fish blood of three different farms}

Table (4) reveals that, a significant increase of cortisol in Locanda farm with $P$ value $(<0.001)$ was recorded, while a significant decrease with a $P$-value of 0.01 was observed in EL-Bats farm when compared to EL-Galini farm, and recording a $P^{*}$-value of 0.01 when compared to Locanda farm. Moreover, there was a non-significant variation of GH in Locanda farm while a significant decrease was determined with a $P$-value of 0.01 in EL-Bats farm when compared to EL-Galini farm. On the other hand, a significant increase of levels of T3 was noticed in Locanda farm with $P$-value $(0.05)$ and $P *$-value (0.01) when compared to Locanda farm and non-significant variation in EL-Bats farm when compared to EL-Galini farm. Additionally, there was non-significant variation of levels of T4 and TSH in both Locanda and EL-Bats farms when compared to EL-Galini farm. 
Table 4. Hormone Levels in Fish Blood of Three Different Farms.

\begin{tabular}{|c|c|c|c|c|}
\hline Hormones & Groups & $\begin{array}{l}\text { ELGalini } \\
\text { Farm }\end{array}$ & $\begin{array}{l}\text { Locanda } \\
\text { Farm }\end{array}$ & $\begin{array}{l}\text { EL-Bats } \\
\text { Farm }\end{array}$ \\
\hline $\begin{array}{c}\text { Cortisol } \\
(\mathrm{mcg} / \mathrm{dL})\end{array}$ & $\begin{array}{c}\text { Range } \\
\text { Means } \pm \mathrm{SD} \\
p \text {-value } \\
P^{*} \text {-value }\end{array}$ & $\begin{array}{c}9.8-9.9 \\
9.85 \pm 0.07\end{array}$ & $\begin{array}{c}15.8-15.9 \\
15.85 \pm 0.07 \\
<0.001\end{array}$ & $\begin{array}{c}4.0-4.4 \\
4.20 \pm 0.28 \\
0.01 \\
0.01\end{array}$ \\
\hline $\begin{array}{l}\text { Growth } \\
\text { hormone } \\
(\mathrm{ng} / \mathrm{mL})\end{array}$ & $\begin{array}{c}\text { Range } \\
\text { Means } \pm \text { SD } \\
p \text {-value } \\
P^{*} \text {-value }\end{array}$ & $\begin{array}{c}0.47-0.49 \\
0.48 \pm 0.10\end{array}$ & $\begin{array}{c}0.52-0.53 \\
0.51 \pm 0.01 \\
0.13\end{array}$ & $\begin{array}{c}0.23-0.24 \\
0.24 \pm 0.01 \\
0.01 \\
0.01\end{array}$ \\
\hline $\begin{array}{c}\text { T3 } \\
\text { (ng/dL) }\end{array}$ & $\begin{array}{c}\text { Range } \\
\text { Means } \pm \text { SD } \\
p \text {-value } \\
P^{*} \text {-value }\end{array}$ & $\begin{array}{c}7.2-9.0 \\
8.10 \pm 1.27\end{array}$ & $\begin{array}{c}19.3-19.4 \\
19.35 \pm 0.70 \\
0.05\end{array}$ & $\begin{array}{c}6.6-7.0 \\
6.80 \pm 0.28 \\
0.3 \\
0.01\end{array}$ \\
\hline $\begin{array}{c}\text { T4 } \\
\text { (ng/dL) }\end{array}$ & $\begin{array}{c}\text { Range } \\
\text { Means } \pm \text { SD } \\
p \text {-value } \\
P^{*} \text {-value }\end{array}$ & $\begin{array}{c}0.7-0.9 \\
0.80 \pm 0.14\end{array}$ & $\begin{array}{c}1.22-1.23 \\
1.23 \pm 0.01 \\
0.1\end{array}$ & $\begin{array}{c}0.7-0.9 \\
0.80 \pm 0.14 \\
1.0 \\
0.1\end{array}$ \\
\hline $\begin{array}{c}\text { TSH } \\
\text { (ng/dL) }\end{array}$ & $\begin{array}{c}\text { Range } \\
\text { Means } \pm \text { SD }\end{array}$ & $\begin{array}{c}0.02-0.02 \\
0.02 \pm 0.01\end{array}$ & $\begin{array}{c}0.04-0.04 \\
0.04 \pm 0.01\end{array}$ & $\begin{array}{c}0.02-0.02 \\
0.02 \pm 0.01\end{array}$ \\
\hline
\end{tabular}

-Data are represented as means $\pm S D$ of 3 farms.; P-value :- when different groups compared with EL-Galini farm.; $P^{*}$-value :when different groups compared with Locanda farm.; $p>0.05$ is non- significant - $p \leq 0.05$ is significant $-S D \pm$ standard deviation

\section{Heavy metal concentrations in fish blood of three different farms}

Fig (6) reveals that, a significant decrease of $\mathrm{Zn}$ was detected in both Locanda and EL-Bats farms with a $P$-value $<0.001$ and 0.001 , respectively when compared to ELGalini farm, and recording a $P^{*}$-value $<0.001$ when compared to Locanda farm. Moreover, there was a significant decrease of $\mathrm{Cu}$ in Locanda farm with $P$-value of 0.01 , while a significant increase was detected in EL-Bats farm with a $P$-value of 0.001 when compared to EL-Galini farm and a $P^{*}$-value of 0.003 when compared to Locanda farm. Furthermore, there was a significant increase in Fe value in Locanda farm with a $P$ value of 0.04. Simultaneously, a significant decrease was recorded in EL-Bats farm with a $P$-value of 0.001 when compared to EL-Galini farm and a $P^{*}$-value $<0.001$ when compared to Locanda farm. Remarkably, $\mathrm{Cd}$ and $\mathrm{Pb}$ levels were not detected in fish blood of the three different farms under study. 


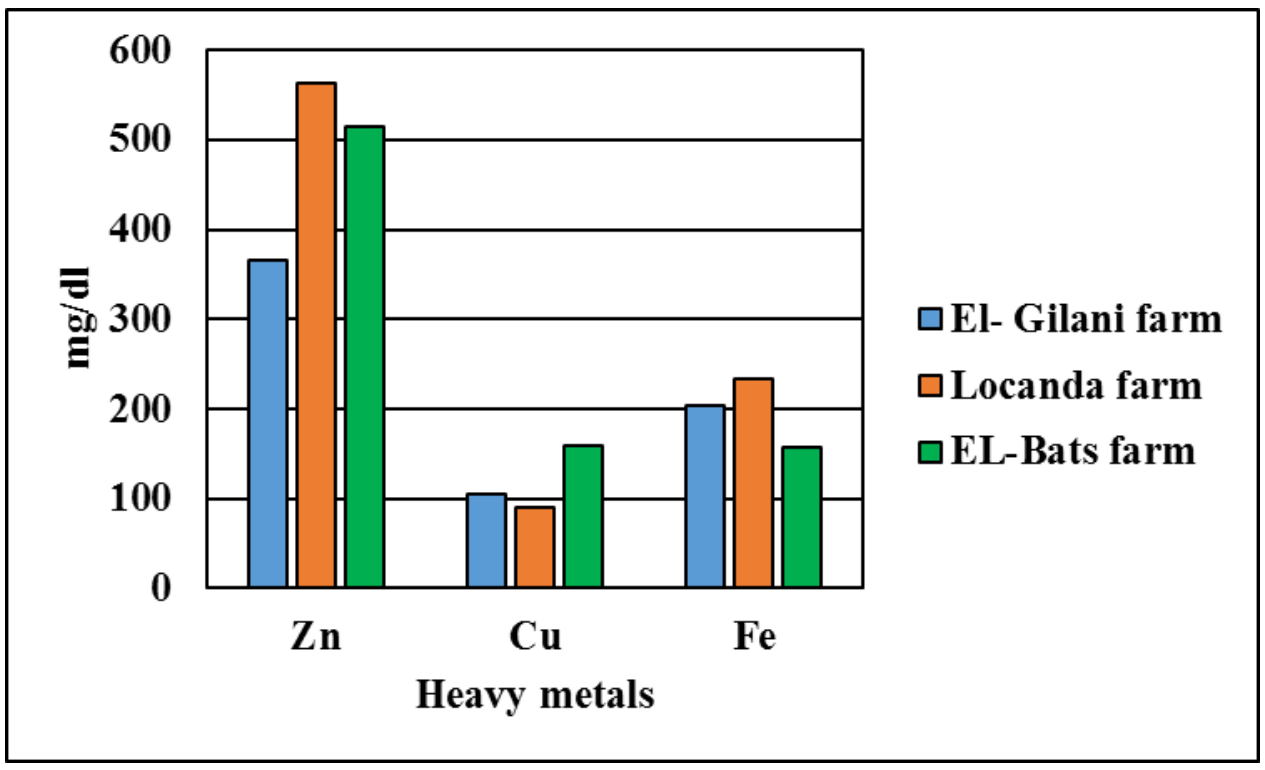

Fig. 6. Heavy Metals Concentrations in Fish Blood of Three Different Farms (mg/dl).

Table 5. Accumulation of Heavy Metals in Fish Liver of Three Different Farms (mg/ kg)

\begin{tabular}{|c|c|c|c|c|}
\hline Heavy metals & Groups & $\begin{array}{l}\text { EL-Galini } \\
\text { farm }\end{array}$ & $\begin{array}{c}\text { Locanda } \\
\text { farm }\end{array}$ & $\begin{array}{c}\text { El-Bats } \\
\text { farm }\end{array}$ \\
\hline $\begin{array}{c}\text { Zinc } \\
(\mathrm{mg} / \mathrm{kg})\end{array}$ & $\begin{array}{c}\text { Range } \\
\text { Means } \pm \text { SD } \\
p \text {-value } \\
P^{*} \text {-value }\end{array}$ & $\begin{array}{l}79.8-79.9 \\
79.8 \pm 0.07\end{array}$ & $\begin{array}{c}41.2-41.3 \\
41.2 \pm 0.07 \\
<0.001\end{array}$ & $\begin{array}{c}27.8-28.0 \\
27.9 \pm 0.14 \\
<0.001 \\
0.001\end{array}$ \\
\hline $\begin{array}{l}\text { Copper } \\
(\mathrm{mg} / \mathrm{kg})\end{array}$ & $\begin{array}{c}\text { Range } \\
\text { Means } \pm \text { SD } p \text { - } \\
\text { value } \\
P^{*} \text {-value }\end{array}$ & $\begin{array}{l}90.4-95.5 \\
92.9 \pm 3.0\end{array}$ & $\begin{array}{c}48.5-52.8 \\
50.7 \pm 3.0 \\
0.001\end{array}$ & $\begin{array}{c}50.2-60.3 \\
57.8 \pm 10.7 \\
0.05 \\
0.05\end{array}$ \\
\hline $\begin{array}{c}\text { Iron } \\
(\mathrm{mg} / \mathrm{kg})\end{array}$ & $\begin{array}{c}\text { Range } \\
\text { Means } \pm \text { SD } p \text { - } \\
\text { value } \\
P^{*} \text {-value }\end{array}$ & $\begin{array}{c}455.3-456.6 \\
455.4 \pm 3.0\end{array}$ & $\begin{array}{c}372.5-373.0 \\
372.8 \pm 0.3 \\
<0.001\end{array}$ & $\begin{array}{c}255.3-262.5 \\
258.9 \pm 5.0 \\
<0.001 \\
0.02\end{array}$ \\
\hline $\begin{array}{c}\text { Lead } \\
(\mathrm{mg} / \mathrm{kg})\end{array}$ & $\begin{array}{c}\text { Range } \\
\text { Means } \pm \text { SD } p \text { - } \\
\text { value } \\
P^{*} \text {-value }\end{array}$ & $\begin{array}{l}0.56-0.58 \\
0.57 \pm 0.01\end{array}$ & $\begin{array}{c}1.0-1.0 \\
1.0 \pm 0.0 \\
0.02\end{array}$ & $\begin{array}{c}1.6-1.6 \\
1.6 \pm 0.0 \\
0.01 \\
0.01\end{array}$ \\
\hline $\begin{array}{c}\text { Cadmium } \\
(\mathrm{mg} / \mathrm{kg})\end{array}$ & $\begin{array}{c}\text { Range } \\
\text { Means } \pm \text { SD } p \text { - } \\
\text { value } \\
P^{*} \text {-value }\end{array}$ & $\begin{array}{c}0.8-0.9 \\
0.85 \pm 0.07\end{array}$ & $\begin{array}{c}0.04-0.04 \\
0.04 \pm 0.00 \\
0.02\end{array}$ & $\begin{array}{c}0.04-0.04 \\
0.04 \pm 0.00 \\
0.04 \\
<0.001\end{array}$ \\
\hline
\end{tabular}

-Data are represented as means $\pm S D$ of 3 farms.; P-value :- when different groups compared to EL-Galini farm.; $P *$-value :when different groups compared to Locanda farm.; $p>0.05$ is non-significant - $p \leq 0.05$ is significant $-S D \pm$ standard deviation

\section{Accumulation of heavy metal concentrations in fish liver of three different farms}

Results recorded in Table (5) show that, there was a significant decrease of $\mathrm{Zn}$, $\mathrm{Cu}, \mathrm{Fe}$ and $\mathrm{Cd}$ in both Locanda and EL-Bats farms with $P$-value $(<0.001,<0.001$ for $\mathrm{Zn})$, $(0.007,0.05$ for $\mathrm{Cu}),(<0.001,<0.001$ for $\mathrm{Fe})$ and $(0.02,0.04$ for $\mathrm{Cd})$ respectively when compared to EL-Galini farm recording a $P^{*}$-value $(0.001,0.05,0.02,<0.001)$ when 
compared to Locanda farm. On the other hand, there was a significant increase of $\mathrm{Pb}$ in both Locanda and EL-Bats farms with $P$-value (0.02 and 0.04) when compared with ELGalini farm and $P^{*}$-value ( 0.001$)$ when compared to Locanda farm. All heavy metals under study showed variation in contamination in all three different farms in the following order $\mathrm{Fe}>\mathrm{Cu}>\mathrm{Zn}>\mathrm{Cd}>\mathrm{Pb}$ in EL-Galini farm. But, they were formed in the following order $\mathrm{Fe}>\mathrm{Cu}>\mathrm{Zn}>\mathrm{Pb}>\mathrm{Cd}$ in both Locanda and EL-Bats farms.

\section{Accumulation of heavy metals in fish muscles of three different farms}

As shown in Table (6), there was a significant decrease of $\mathrm{Zn}$ and Fe with $P$-value $(0.001,0.002$ for $\mathrm{Zn})$ and $(0.003,<0.001$ for Fe), respectively in Locanda and EL-Bats farms when compared to EL-Galini farm and $P^{*}$-value $(0.002)$ when compared to Locanda farm. Additionally, there was a non- significant variation of $\mathrm{Cu}$ in both Locanda and EL-Bats farms when compared to EL-Galini farm. But, neither $\mathrm{Cd}$ nor $\mathrm{Pb}$ was detected in fish muscle at the three different farms under study. All heavy metals under study showed variation in contamination in all three different farms in the following order $\mathrm{Fe}>\mathrm{Cu}>\mathrm{Zn}$.

Table 6. Accumulation of Heavy Metals in Fish Muscles of Three Different Farms (mg/ $\mathrm{kg})$.

\begin{tabular}{|c|c|c|c|c|}
\hline \multicolumn{2}{|c|}{ Groups } & $\begin{array}{c}\text { EL-Galini } \\
\text { Farm }\end{array}$ & $\begin{array}{c}\text { Locanda } \\
\text { Farm }\end{array}$ & $\begin{array}{c}\text { EL-Bats } \\
\text { Farm }\end{array}$ \\
\hline & Range & $47.7-47.9$ & $34.3-34.4$ & $18.9-18.9$ \\
Zinc & Means \pm SD & $47.8 \pm 0.14$ & $34.3 \pm 0.07$ & $18.9 \pm 0.0$ \\
$(\mathrm{mg} / \mathrm{kg})$ & $p$-value & & 0.001 & 0.002 \\
& $P^{*}$-value & & & 0.002 \\
\hline & Range & $6.9-8.7$ & $3.7-9.2$ & $4.1-4.4$ \\
Copper & Means \pm SD & $7.55 \pm 1.6$ & $6.45 \pm 3.8$ & $4.25 \pm 0.21$ \\
$(\mathrm{mg} / \mathrm{kg})$ & $p$-value & & 0.7 & 0.2 \\
& $P^{*}$-value & & & 0.5 \\
\hline & Range & $1181.2-1197.2$ & $221.9-225.7$ & $238.9-253.7$ \\
Iron & Means \pm SD & $1189.2 \pm 11.3$ & $223.8 \pm 2.6$ & $246.3 \pm 10.4$ \\
$(\mathrm{mg} / \mathrm{kg})$ & $p$-value & & $<0.001$ & $<0.001$ \\
& $P^{*}$-value & & & 0.1 \\
\hline Lead & Range & - & - & - \\
$(\mathrm{mg} / \mathrm{kg})$ & Means \pm SD & Not detected & Not detected & Not detected \\
\hline Cadmium & Range & - & - & - \\
$(\mathrm{mg} / \mathrm{kg})$ & Means \pm SD & Not detected & Not detected & Not detected \\
\hline
\end{tabular}

-Data are represented as means $\pm S D$ of 3 farms.; P-value :- when different groups compared to EL-Galini farm.; $P^{*}$-value :when different groups compared to Locanda farm.; $p>0.05$ is non- significant - $p \leq 0.05$ is significant - SD \pm standard deviation

\section{Accumulation of some heavy metals in fish gills of three different farms}

Table (7) obtains a significant increase of $\mathrm{Zn}$ and $\mathrm{Pb}$ in both Locanda and EL-Bats farms with a $P$-value of $0.01,0.001$ for $\mathrm{Zn}$ and $0.05,0.05$ for $\mathrm{Pb}$, respectively when compared to EL-Galini farm and recorded a $P^{*}$-value of 0.005 and 0.06 when compared to Locanda farm. But, a significant decrease of Fe was recorded in both Locanda and 
EL-Bats farms with a $P$-value $<0.001$ and $<0.001)$ respectively, when compared with ELGalini farm and $P^{*}$-value (0.01) when compared with Locanda farm. Furthermore, a nonsignificant variation in levels of $\mathrm{Cu}$ was detected in both Locanda and EL-Bats farms when compared to EL-Galini farm, Cd recorded high levels in EL-Bats farm compared with EL-Galini and Locanda farms. All heavy metals under study showed variation in contamination in all three different farms in following order $\mathrm{Fe}>\mathrm{Zn}>\mathrm{Cu}>\mathrm{Pb}>\mathrm{Cd}$.

Table 7. Accumulation of Heavy Metals in Fish Gills of Three Different Farm (mg/kg).

\begin{tabular}{|c|c|c|c|c|}
\hline & $\begin{array}{l}\text { EL-Galini } \\
\text { Farm }\end{array}$ & $\begin{array}{l}\text { Locanda } \\
\text { Farm }\end{array}$ & $\begin{array}{l}\text { EL-Bats } \\
\text { Farm }\end{array}$ \\
\hline $\begin{array}{c}\mathrm{Zinc} \\
(\mathrm{mg} / \mathrm{kg})\end{array}$ & $\begin{array}{c}\text { Range } \\
\text { Means } \pm \text { SD } \\
p \text {-value } \\
P^{*} \text {-value }\end{array}$ & $\begin{array}{c}40.3-40.4 \\
40.35 \pm 0.07\end{array}$ & $\begin{array}{c}45.2-45.5 \\
45.35 \pm 0.2 \\
0.01\end{array}$ & $\begin{array}{c}65.3-65.3 \\
65.30 \pm 0.0 \\
0.001 \\
0.005\end{array}$ \\
\hline $\begin{array}{l}\text { Copper } \\
\text { (mg/kg) }\end{array}$ & $\begin{array}{c}\text { Range } \\
\text { Means } \pm \text { SD } \\
p \text {-value } \\
P^{*} \text {-value }\end{array}$ & $\begin{array}{c}3.0-4.0 \\
3.40 \pm 0.5\end{array}$ & $\begin{array}{c}4.0-8.0 \\
5.90 \pm 2.4 \\
0.3\end{array}$ & $\begin{array}{c}2.0-5.0 \\
3.50 \pm 2.4 \\
0.9 \\
0.4\end{array}$ \\
\hline $\begin{array}{c}\text { Iron } \\
(\mathrm{mg} / \mathrm{kg})\end{array}$ & $\begin{array}{c}\text { Range } \\
\text { Means } \pm \text { SD } \\
p \text {-value } \\
P^{*} \text {-value }\end{array}$ & $\begin{array}{c}1837.6-1852.0 \\
1844.8 \pm 10.1\end{array}$ & $\begin{array}{c}402-409.6 \\
405.3 \pm 5.4 \\
0.0\end{array}$ & $\begin{array}{c}515.6-528 \\
521.8 \pm 8.7 \\
<0.001 \\
0.01\end{array}$ \\
\hline $\begin{array}{c}\text { Lead } \\
(\mathrm{mg} / \mathrm{kg})\end{array}$ & $\begin{array}{c}\text { Range } \\
\text { Means } \pm \text { SD } \\
p \text {-value } \\
P^{*} \text {-value }\end{array}$ & $\begin{array}{c}0.2-0.2 \\
0.2 \pm 0.0\end{array}$ & $\begin{array}{c}0.35-0.4 \\
0.36 \pm 0.0 \\
0.05\end{array}$ & $\begin{array}{c}0.8-0.9 \\
0.85 \pm 0.07 \\
0.05 \\
0.06\end{array}$ \\
\hline $\begin{array}{c}\text { Cadmium } \\
(\mathrm{mg} / \mathrm{kg})\end{array}$ & $\begin{array}{c}\text { Range } \\
\text { Means } \pm \text { SD }\end{array}$ & $\begin{array}{c}0.1-0.1 \\
0.1 \pm 0.0\end{array}$ & $\begin{array}{c}0.1-0.1 \\
0.1 \pm 0.0\end{array}$ & $\begin{array}{c}0.0-0.0 \\
0.04 \pm 0.0\end{array}$ \\
\hline
\end{tabular}

-Data are represented as means $\pm S D$ of 3 farms.; P-value :- when different groups compared with EL-Galini farm.; $P *$-value :when different groups compared with Locanda farm.; $p>0.05$ is non- significant - $p \leq 0.05$ is significant $-S D \pm$ standard deviation

\section{Accumulation of heavy metals in fish skin of three different farms}

Table (8) reveals that, there was a significant decrease of $\mathrm{Zn}$ and Fe with $P$-value $(<0.001,0.01$ for $\mathrm{Zn})$ and $(0.001,<0.001$ for $\mathrm{Fe})$ respectively in Locanda and EL-Bats farms when compared with EL-Galini farm and $P^{*}$-value $(<0.001,0.04)$ when compared with Locanda farm. In addition, there was non- significant variation of levels with mean value \pm S.D of $\mathrm{Cu}$ in both Locanda and EL-Bats farms when compared to EL-Galini farm. While, neither $\mathrm{Cd}$ nor $\mathrm{Pb}$ was detected in skin organ of fish at the three different farms under study except in EL-Bats farm that recorded levels with mean value \pm S.D (1.4 \pm 0.07$)$. This was accompanied with the fact that fish were found with enlarged gallbladder compared to EL-Galini farm fish pop eyes (exophthalmia), darkening, loss of appetite, swollen gallbladder, brown/dark areas in the liver and a lot of fish died in this pond due to streptococci bacteria. All heavy metals under study showed variation in contamination in the three different farms in following order $\mathrm{Fe}>\mathrm{Zn}>\mathrm{Cu}$. 
Table 8. Accumulation of Heavy Metals in Fish Skin of Three Different Farms (mg/kg).

\begin{tabular}{|c|c|c|c|c|}
\hline \multicolumn{2}{|c|}{$\begin{array}{c}\text { Groups } \\
\text { Heavy metals }\end{array}$} & $\begin{array}{c}\text { EL-Galini } \\
\text { Farm }\end{array}$ & $\begin{array}{c}\text { Locanda } \\
\text { Farm }\end{array}$ & $\begin{array}{c}\text { EL-Bats } \\
\text { Farm }\end{array}$ \\
\hline \multirow{2}{*}{ Zinc } & Range & $143.6-144.7$ & $90.2-90.9$ & $133.5-134.1$ \\
$(\mathrm{mg} / \mathrm{kg})$ & $\begin{array}{c}\text { Means } \pm \text { SD } \\
p \text {-value } \\
P^{*} \text {-value }\end{array}$ & $144.15 \pm 0.7$ & $\begin{array}{c}90.55 \pm 0.5 \\
<0.001\end{array}$ & $\begin{array}{c}133.8 \pm 0.4 \\
0.01\end{array}$ \\
& Range & $2.36-5.50$ & $1.10-4.90$ & $3.80-6.70$ \\
Copper & Means \pm SD & $3.39 \pm 2.2$ & $3.00 \pm 2.6$ & $5.25 \pm 2.0$ \\
$(\mathrm{mg} / \mathrm{kg})$ & $p$-value & & 0.7 & 0.6 \\
& $P^{*}$-value & & & 0.4 \\
\hline & Range & $3330-3330$ & $279-293$ & $402-402$ \\
Iron & Means \pm SD & $3330 \pm 0.00$ & $285.6 \pm 9.8$ & $401.8 \pm 0.2$ \\
$(\mathrm{mg} / \mathrm{kg})$ & $p$-value & & 0.001 & 0.00 \\
& $P^{*}$-value & & & 0.04 \\
\hline Lead & Range & - & - & $1.0-2.0$ \\
$(\mathrm{mg} / \mathrm{kg})$ & Means \pm SD & Not detected & Not detected & $1.4 \pm 0.07$ \\
\hline Cadmium & Range & - & - & - \\
$(\mathrm{mg} / \mathrm{kg})$ & Means \pm SD & Not detected & Not detected & Not detected \\
\hline
\end{tabular}

-Data are represented as means $\pm S D$ of 3 farms.; P-value :- when different groups compared to EL-Galini farm.; $P^{*}$-value :when different groups compared to Locanda farm.; $p>0.05$ is non-significant - $p \leq 0.05$ is significant - SD \pm standard deviation

\section{DISCUSSION}

Heavy metals in the aquatic environment is a main problem due to its toxicity and danger to plant and animal life, that affect the natural ecological balance. Residue is the net build-up of substances from water in an aquatic organism that results from enhanced uptake and slow elimination of such substance (Bhattacharya et al , 2008). The current study recorded that the values of heavy metals showed relative variation among three different drains. Results showed that, the order of heavy metals were $\mathrm{Fe}>\mathrm{Zn}>\mathrm{Cu}>\mathrm{Pb}>$ $\mathrm{Cd}$ in all three different drains. Additionally, the values of heavy metals showed relative variation $\mathrm{Fe}>\mathrm{Zn}>\mathrm{Cu}>\mathrm{Pb}>\mathrm{Cd}$ in all three different farms that agrees with the result reported in the study of Adham et al. (2002) who studied contamination of heavy metals $(\mathrm{Fe}, \mathrm{Cu}, \mathrm{Zn}, \mathrm{Cd}$ and others) at Maryut lake in difference stations. Moreover, the present finding coincides with that of Ali and Abdel-Satar (2005) who studied the heavy metals (Fe, $\mathrm{Mn}, \mathrm{Zn}, \mathrm{Cu}, \mathrm{Pb}$ and $\mathrm{Cd}$ ) in water of some fish farms in EL-Fayoum (Goda1,2; ELshoura and shalakany). In addition, Zaghloul (2008), Abdel-Satar et al. (2010) and Gohar et al. (2018) studied contamination of heavy metals, such as $\mathrm{Fe}, \mathrm{Zn}, \mathrm{Cu}, \mathrm{Pb}, \mathrm{Cd}$ in water samples of El-Bats drainage canal and El-Wadi drainage canal. Moreover, Emara et al. (2015) detected accumulation of heavy metals of $\mathrm{Fe}, \mathrm{Zn}, \mathrm{Cu}, \mathrm{Pb}, \mathrm{Cd}$ at $\mathrm{Al}$ Abbassa and Shader Azzam fish farms. It is worth mentioning that, Abd El-Atti et al. (2018) reported that, water collected from Qarun and Burullus Lakes had high levels of lead and cadmium. The concentration of $\mathrm{Pb}$ and $\mathrm{Cd}$ in Lake Qarun were much lower than that of Burullus Lake. As any pollutants in water has negative impact on survival of fish, 
water must be purified from those pollutants, especially heavy metals. Thus, the present study was concerned about treatment of drainage water which pour into fish farms by using simple and cheap treatment methods, such as treatment by pumpkin (Cucurbita pepo) and eggplant (Solanum melongena). Heavy metal concentrations in El- Bats drainage before and after treatment by pumpkin showed a relative variation among different heavy metals after treatment with pumpkin. It is clear from obtained results that, the removal of the different heavy metals follow the order of: $\mathrm{Fe}>\mathrm{Cd}>\mathrm{Zn}>\mathrm{Cu}>\mathrm{Pb}$. The maximum removal was $77 \%$ for $\mathrm{Fe}$, and the minimum was $50 \%$ for $\mathrm{Pb}$. It is clear from obtained results that, the order of removal of the different heavy metals were arranged as follows: $\mathrm{Fe}>\mathrm{Cd}>\mathrm{Cu}>\mathrm{Zn}$ and $\mathrm{Pb}(\mathrm{Zn}$ and $\mathrm{Pb}$ had equal removal percentage). The maximum removal was $88 \%$ for $\mathrm{Fe}$ and the minimum was $25 \%$ for $\mathrm{Zn}$ and $\mathrm{Pb}$ under effect of treatment by eggplant. Compression between the two methods for heavy metals removal showed that, pumpkin was good for treating $\mathrm{Zn}$ and $\mathrm{Pb}$ the maximum removal for $\mathrm{Zn}$ was $65 \%$ and for $\mathrm{Pb}$ the value was $50 \%$. While eggplant was good for treating $\mathrm{Fe}$, $\mathrm{Cd}$ and $\mathrm{Cu}$ recording maximum values $(88 \%, 78 \%$ and $77 \%$ respectively). The aforementioned results are similar to those of Samuel et al. (2016) who stated that, pumpkin was an excellent adsorbent for ameliorates of $\mathrm{Cu}$ (II) and $\mathrm{Ni}$ (II) ions. Additionally, Deepthi et al. (2017) reported that, the natural coagulants pumpkin seeds have the potential to remove copper from water, while Karimi et al. (2018) concluded that, treated eggplant peel used as an adsorbent for $\mathrm{Pb}$ from aqueous solution recorded good results for lead removal from wastewater. Analyses of serum biochemical constituents' levels have shown useful information in detection and diagnosis of metabolic orders and diseases in fishes (Ferrari et al., 2007). The present study detected variation in values of biochemical parameter levels recording a significant increase in both Locanda and EL-Bats farms when compared to EL-Galini farm under study which indicated disrupted carbohydrates breakdown metabolism. The promote breakdown of liver and muscle glycogen via glycogenesis mediated may be due to adrenocortical and catecholamine hormones and also reduction of insulin secretion (Gad, 1999). The current result concurs with that of Adham et al. (2002) who studied the level of glucose in the Nile tilapia at Maryut lake and Osman et al. (2018) who reported that, glucose in the blood serum of the Nile tilapia increased in Aswan, Kena, Assiut, Beni Suef, Damietta and Rosetta. In addition, the present study recorded a significant decrease of creatinine, CK and AST in both Locanda and EL-Bats farms when compared to EL-Galini farm in addition to urea in Locanda farm. However, a significant increase was detected in ELBats farm when compared to EL-Galini farm. Moreover, the present findings detected a significant increase of ALT in Locanda farm, while a significant decrease was spotted in EL-Bats farm when compared to EL-Galini farm. This result is similar to that of Zaghloul (2008) who reported that, there was a significant increase in serum AST and ALT of Clarias gariepinus collected from the agricultural drainage canals, El-Bats and El-Wadi drains. Addingly, Osman et al. (2018) stated that, ALT and AST increased in blood serum of the Nile tilapia in Aswan, Kena, Assiut, Beni Suef, Damietta and Rosetta. This increase in the studied enzymes activities may be attributed to the damage in the liver tissues, liver enzyme inhibition by the action of the recorded bio accumulated heavy metals disturbance in Kreb's cycle as reported by Sanchez et al. (2005). The present study determined that, levels of CK showed an increase in the Nile tilapia of EL-Galini farm compared to others. This result agrees with that of Adham et al. (2002) who 
obtained level of CK in serum of the Nile tilapia at Maryut Lake and Yousaf and Powell (2012) who studied levels of CK in Atlantic salmon. ALP showed an increase in the Nile tilapia of EL-Bats farm compared to others; and agrees with the result reported by Adham et al. (2002) recording high increase in serum of the Nile tilapia fish at Maryut Lake. Additionally, Dorcas and Solomon (2014) and Osman et al. (2018) showed that there was variation of values of hormone parameter levels (T3, T4, TSH, GH and Cortisol) of the Nile tilapia in three different farms with significant increase in levels of all hormones under study in the blood of the Nile tilapia of Locanda farm compared to EL-Galini and EL-Bats farms, respectively. Consequently, the present results discussed residue of heavy metals of $\mathrm{Fe}, \mathrm{Cu}, \mathrm{Zn}, \mathrm{Cd}$ and $\mathrm{Pb}$ in the blood of the Nile tilapia in three different farms. Moreover, it revealed that, there is a variation in values of heavy metals of the Nile tilapia fish blood and detectable in order of: $\mathrm{Zn}>\mathrm{Fe}>\mathrm{Cu}$ in fish of EL-Galini Farm and Locanda farm. While, the order was $\mathrm{Zn}>\mathrm{Cu}>\mathrm{Fe}$ in fish of EL-Bats farm and not detectable for $\mathrm{Pb}$ and $\mathrm{Cd}$ in Locanda and EL-Gilini fish farms, but detected in ELBats. Residue of heavy metals varied between species, ages, sex and organs; liver and gills have metabolic activity in which high levels of metals were found. Nevertheless, muscles showed low metabolic activity where less level of heavy metals were found (Younis et al., 2015). Residue of heavy metals in different organs, such as liver, gills, muscles and skin discussed in the present study showed that, all heavy metals under study showed variation in residue in all three different farms. The order was $\mathrm{Fe}>\mathrm{Cu}>\mathrm{Zn}$ and $\mathrm{Cd}>\mathrm{Pb}$ in the Nile tilapia fish liver organ, but in fish muscles the order was $\mathrm{Fe}>\mathrm{Zn}>\mathrm{Cu}$ with no detectable $\mathrm{Pb}$ or $\mathrm{Cd}$. While, in gills, the order was $\mathrm{Fe}>\mathrm{Zn}>\mathrm{Cu}>\mathrm{Pb}>\mathrm{Cd}$. On the other hand, the residue of heavy metals in fish skin of three different farm was in the following order: $\mathrm{Fe}>\mathrm{Zn}>\mathrm{Cu}$, and no detectable $\mathrm{Pb}$ or $\mathrm{Cd}$ was spotted except in fish skin of EL-Bats $\mathrm{Pb}$ due to the existence of streptococci bacteria. This result is similar to those of Yacoub et al. (2008), Ghannam et al. (2014) and Talab et al. (2014). The previous authors found that, the order of heavy metals was $\mathrm{Fe}>\mathrm{Zn}>\mathrm{Cu}>\mathrm{Cd}>\mathrm{Pb}$ in liver, gills, muscles and intestine organs of O. niloticus (L.) living in fish farm in El Fayoum Province that coincides with the results of Kumar $\boldsymbol{e t}$ al. (2011), Shivakumar $\boldsymbol{e t}$ al. (2014), Ghannam et al. (2015a, b), Talab et al. (2016) and Abd El-Atti et al. (2018).

\section{CONCLUSION}

The present study was concerned with the effect of different drains on the fish farms by the examination of the concentration of different heavy metals in water and fish collected from drains and farms. The Nile tilapia was used as a biomarker of pollution with heavy metals by detecting their accumulation in different fish organs and blood. Water treatment using low adsorbent (pumpkin and eggplant) to remove this heavy metals showed that, pumpkin was good for treating $\mathrm{Zn}$ and $\mathrm{Pb}$, while eggplant was good for treating $\mathrm{Fe}, \mathrm{Cd}$ and $\mathrm{Cu}$.Additionally, this work addressed the influence of heavy metals on fish biochemistry by detecting glucose, liver and kidney functions, cortisol hormone, growth and thyroid hormones. All the results emphasized that contamination with heavy metals such as zinc, iron, copper, lead and cadmium in water of drainage and fish farms is very hazardous to aquatic life and fish culture. 


\section{REFERENCES}

Abd El-Atti , H.E.; G. E. M. S. and Ekraim ,Y.M. (2018). Harmful effects of water pollution on some physiological responses of the Nile tilapia (Oreochromis niloticus) in both Qarun and Burullus Lakes. The Egyptian Journal of Hospital Medicine .,2 (2):4021- 4025

Abdel-Satar, A.M.; Goher ,M.E. and Sayed , M.F. (2010). Recent Environmental Changes in Water and Sediment Quality of Lake Qarun, Egypt, Journal international fisheries and aquatic science.,5(2):56-69.

Abdel-Warith,A. A.; Younis, E. M.; Al-Asgah, N.A. and Wahbi, O.M. (2011). Effect of zinc toxicity on liver histology of nile tilapia, Oreochromisniloticus. Sci. Res. Essays., 6: 3760-3769.

Adham, K.G.; Ibrahim, H.M.; Hamed, S.S. and Saleh, R. A. (2002) Blood chemistry of the Nile tilapia,Oreochromis niloticus under the impact of water pollution Aquatic Ecology., 36: 549-557.

Adhikari,S.; Sarkar, B.; Chatterjee, A.; Mahapatra , C. T. and Ayyappan, S. (2004). Effects of cypermethrin and carbofuran on certain hematological parameters and prediction of their recovery in a freshwater teleost, Labeorohita (Hamilton).Ecotoxicol. Environ. Safety., 58(2):220-226.

Ali, M. H. H. and Abd EL-Satar, A. M. (2005). studies of some heavy metals in water, sediment, fish and fish diets in some fish farms in EL-Fayoum Provinces, Egyptian Journal of Aquatic Research. , 31:261-273.

Barnes, J. (2014). Mixing waters: The reuse of agricultural drainage water in 458 Egypt. Geoforum. 57:181-191. http://dx.doi.org/10.1016/j.geoforum.2012.11.019.

Baum, H. B. A.; Katznelson, L.; Sherman , J. C.; Biller, B. M. K.; Hayden, D. L.; Schoenfeld, D. A.; Cannistraro, K. E.; and Klibanski, A. (1998). Effects of physiological growth hormone $(\mathrm{GH})$ therapy on cognition and quality of life in patientswithadult-onset GH deficiency. J. Clin. Endocr.Metab., 83:3184-3189.

Bhattacharya, A. K.; Mandal, S. N. and Das, S. K. (2008). Heavy metals accumulation in water, sediment and tissues of different edible fishes in upper stretch of Gangetic West Bengal. Trends Applied Sci.Res.,3:61-68.

Chopra, I. J. (1972). A radio immunoassay for measurement of thyroxine in unextracted serum J Clin EndocrinolMetab., 34:938-947.

Cnaani ,A.; Tinman, S.; Avidar, Y., Ron, M. and Hulata, G. (2004). Comparative study of biochemical parameters in response to stress in Oreochromis aureus, $O$. mossambicus and two strains of $O$. niloticus. Aquaculture Research, Stirling.,35:.434:440.

Dalrymple, H. (2015). Broadside eulogy dedicated to Patrick, Earl of Marchmount, Sir Hugh Dalrymple, and others". National Library of Scotland. Retrieved 5 April.

Deepthi, P.; Sarala, C.; Kumar , S. P., and Mukkanti , K. (2017). Cucurbitapepo as a Coagulant Aid for Copper Removal, International Journal of Engineering Research \& Technology (IJERT).,6:9.

Dorcas, I. K. and Solomon, R. J.(2014). Calculation Of Liver Function Test In Clarias gariepinus Collected From Three Commercial Fish Ponds Nature and Science.,12 (10). 
El-Nemeki , F. A.; Ali ,N. A.; Zeinhom, M. M. and Radwan ,O. A. (2008). Impacts of different water resources on the ecological parameters and the quality of tilapia production at El-Abbassa fish farms in Egypt $8^{\text {th }}$ international symposium on tilapia in aquaculture., 491-512.

Emara , M. M.; Farag, R.S.; Dawah, A. A. and Fathi, M .(2015). Assessment of heavy metals concentration in water and edible tissues of Nile tilapia (Oreochromis niloticus) from two Fish farms irrigated with different water sources, Egypt International Journal of Environment.,4:108-115.

Ferrari, A.; Venturino. A .; and de D’Angelo, P. A. M. (2007). Effects of carbaryl and azinphos methyl on juvenile rainbow trout (Oncorhynchus mykiss) detoxifying enzymes. Pesticide Biochemistry and Physiology .,88 (2):134-142.

Gabbadon, P. and DeSouza. G. (2008). Fish farm ponds amanual for their Design,Construction and Maintenance, 1-18.

Gad, N.S. (1999). Bioassay studies for assessment of the effect of some pesticides on Tilpia zillii living in fresh and saline water Ph.d. thesis Fac.Sci. Ain shams university.

Gajek, R.; Barley F., and She .J. (2013). "Determination of essential and toxic metals in blood by ICP-MS with calibration in synthetic matrix" Analytical Methods., 5:21932202.

German clinical chemistry society (1977). Reference procedures for the determination of creatine kinase activity. Clin Chem Clin Biochem., 15 : 249 -54.

Ghannam H. E.; El Haddad E. S. and Talab A. S. (2015a). Bioaccumulation of heavy metals in tilapia fish organs. Journal of Biodiversity and Environmental Sciences, 88-99.

Ghannam H. E.; Talab A. S. and Elewa A. A. (2015b). Impact of seasonal changes on the quality of water and fish from Abu Za'baal Lakes. Journal of Bioscience and Applied Research, 1(4):192-199.

Ghannam H. E.; Talab A. S.; Gaber S. E. and Jahin H. S. (2014). Assessment of heavy metals distribution in some freshwater fish organs using inductively coupled plasma optical emission spectrometry (ICP-OES). Ecology, Environment and Conservation Journal, 20 (2): 63-74.

Goher, M. E.; El-Rouby W. M. A.; El-Dek S .I..; El-Sayed S. M. and Noaemy. S. G. (2018) Water quality assessment of Qarun Lake and heavy metals decontamination from its drains using nanocomposites The $4^{\text {th }}$ International Conference on Advanced Applied Sciences.

Goldberg, E. D. (1963). Geochronologywithlead-210. In: Symposium on radioactive dating, Athens,. Vienna, InternationalAtomic Energy Agency.,121-131.

Jezierska, B. and Witeska, M. (2006). The metal uptake and accumulation in fish living in polluted waters. Soil and Water Pollution Monitoring Protection and Remediation, 69:107-114.

Karimi, M. H.; Davoodi S. M.; Dursun A. Y.; Ehsan. M. R.; Iman- Karimpour. and Elham- Ameri. (2018). Application of treated eggplant peel as a low-costad sorbent for water treatment toward elimination of Pb2 Adsorption Science \& Technology., 132

Kumar, B.; Mukherjee, D. P. ; Sanjay- Kumar.; Meenu- Mishra.; DevPrakash, Singh S. K. and Sharma, C. S. (2011).Bioaccumulation of heavy metals in muscle 
tissue of fishes from selected aquaculture ponds in east Kolkata wetlands Annals of Biological Research.,2 (5) :125-134.

Min, S.,; Han J. and Shin, E. (2004). Improvement of cadmium ion removal by base treatment of juniper fiber. Water Research.,38(5):1289-1295.

Morimoto, K. and Inouye .K. (1997). Human Thyroid- Stimulating Hormone (TSH) ELISA Kit , MET-5052: Human Adiponectin ELISA Kit J. Immunol. Methods.,205:81-90.

Osman, A. G. M.; AbouelFadl, K. Y.; Abd El Reheem , A. M.; Mahmoud ,U. M.; Werner- Kloas. and Moustafa , M. A. ( 2018). Blood biomarkers in Nile tilapia Oreochromis niloticus and African catfish Clarias gariepinus to evaluate water quality of the River Nile. Journal of Fisheries Sciences.,12(1):001-015.

Saeed , S. M. and Shaker I. M. (2008). Assessment of heavy metals pollution in waters and sediments and their effects on Oreochromis niloticus in the northern delta lakes, Egypt International Symposium on Tilapia in Aquaculture. 475-485.

Samuel, J.; Shanthi, S. and Vashantha .R. (2016). Utilization of agro-waste material as potential adsorbent for removal of $\mathrm{Cu}$ (II) and $\mathrm{Ni}$ (II) ions from aqueous phase. Indian Journal of Advances in Chemical Science., 4(3):346-354

Sanchez ,W.; Palluel , O.; Meunier ,L.; Coquery, M.; Porcher, J.M. and Ait-Aissa, S. (2005). Copper-induced oxidative stress in three-spined stickleback: relationship with hepatic metal levels. Environ. Toxicol.Pharmacol. , 19:171-183.

Shivakumar, C.K.;Thippeswamy, B.; Tejaswikumar, M.V.; Prashanthakumara, S.M. (2014). Bioaccumulation of heavy metals and its effect on organs of edible fishes located in Bhadra River, Karnataka. International Journal of Research in Fisheries and Aquaculture., 4:90-98.

SPSS, (2008). Statistical Package For Social Science (for Windows). Release 17 Copyright (C), SPSS Inc., Chicago,USA.

Talab A.S.; Jahin S.H.; Gaber S.E. and Ghannam H.E. (2014). Influence of Modern Cooking Techniques on Heavy Metals Concentrations of Some Freshwater Fish Fillets. Research Journal of Applied Sciences, Engineering and Technology, 8(1): 69-75.

Talab A. S.; Mohamed E. Goher; Hala E. Ghannam and Mohamed H. Abdo (2016). Chemical compositions and heavy metal contents of Oreochromis niloticus from the main irrigated canals (rayahs) of Nile Delta. Egyptian Journal of Aquatic Research (2016) 42, 23-31.

Tietz, N. W.; Rinker, A.D. and Shaw, L.M. (1983). Methods for the measurement of catalytic concentration of enzymes. Part 5. IFCC method for alkaline phosphatase. J ClinChemClin Biochem.,21:731-748.

Trinder, P. (1969). Determination of glucose inblood using glucose oxidase with an alternative oxygen receptor, Ann. Clin.Biochem.. 6:24-27.

Tunn, S.; Pappert, G.; Willnow, P. and Krieg,M.(1990). Multicentre evaluation of an enzyme immunoassay for cortisol determination. J ClinChemClinBiochem,.28:929935.

Wild, D. (1994). Immunoassay Handbook, Stockton Press,339.

Yacoub, A.M. and Gad, N.S. (2012). Accumulation of some heavy metals and biochemical alterations in muscles of Oreochromis niloticus from the River Nile in Upper Egypt. Engineering (IJESE) .,3:1-10. 
Yacoub, M.A.; Mahmoud S.A. and Tayel S. (2008). Health Status of Oreachromis niloticous in fish farm irrigated with drainage water in EL- Fayoum provinces, Egyptian Journal of Aquatic Research. ,34 :161-175.

Younis, E. M.; Abdel-Warith A. A. and Al-Asgah N. A. (2012). Hematological and enzymatic responses of Nile tilapia Oreochromis niloticus during short and long term sublethal exposure to zinc African Journal of Biotechnology.,11(19):4442- 4446.

Younis,A. M.; Amin H. F.; Alkaladi A. and Mosleh. Y. Y. I. (2015). Bioaccumulation of heavy metals in fish, squids and crustaceans from the Red Sea, Jeddah Coast, Saudi Arabia Open Journal of Marine Science., 5: 369-378.

Yousaf, M. N. and Powell. M. D. (2012). The Effects of heart and skeletal muscle inflammation and cardiomyopathy syndrome on creatine kinase and lactate dehydrogenase levels in Atlantic salmon (Salmo salarL.) The Scientific World Journal, Volume ,9p.

Zaghloul, K. H. (2008). Ecotoxicological recovery of agricultural drainage water impact on clarias gariepinus in El-Fayoum governorate, Egypt. J. Exp. Biol. (Zool.). 4: 7379. 